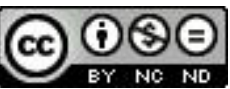

\section{Escrita Autobiográfica e História da Educação Matemática*}

\section{Autobiographical Writing and History of Mathematics Education}

\author{
Maria Laura Magalhães Gomes**
}

\begin{abstract}
Resumo
Focalizando as possibilidades de conexão entre escrita autobiográfica e história da educação matemática, este artigo apresenta concepções de escrita autobiográfica, um panorama de seu desenvolvimento histórico, uma tipologia dos escritos autobiográficos e uma discussão de natureza teórico-metodológica relativa às principais questões a ser consideradas nas pesquisas historiográficas que os utilizem como fonte ou como objeto.
\end{abstract}

Palavras-chave: Escrita Autobiográfica. História da Educação Matemática.

\begin{abstract}
This article focuses on the possibilities of connection between autobiographical writing and history of mathematics education. The paper discusses conceptions of autobiographical writing and presents a panorama of their historical development. It also presents a typology of autobiographical texts and examines theoretical and methodological issues concerning historical research which uses those texts as sources or subjects of investigation.

Keywords: Autobiographical Writing. History of Mathematics Education.

\footnotetext{
* Trabalho realizado com apoio de bolsa de pós-doutorado sênior do CNPq.

** Doutora em Educação, Universidade Estadual de Campinas (UNICAMP). Professora do Departamento de Matemática e do Programa de Pós-graduação em Educação da Universidade Federal de Minas Gerais (UFMG), Belo Horizonte, MG, Brasil. Endereço para correspondência: Departamento de Matemática. ICEx-UFMG. Av. Antônio Carlos, 6627. Cidade Universitária. Pampulha. CEP 321270-901. Belo Horizonte. MG, Brasil. E-mail: laura@mat.ufmg.br
} 


\section{Introdução: escrita autobiográfica}

O que é escrita autobiográfica? O que diferencia os escritos autobiográficos de outros escritos? A ideia primeira que nos ocorre para tentar conceituar a autobiografia é a da biografia de um personagem escrita por ele mesmo. Quando pensamos em escrita autobiográfica, não é raro, porém, que nos lembremos dos livros de memórias, dos diários e das cartas. No entanto, esse tipo de escrita, também designada como escrita auto-referencial ou escrita de si, tem sido entendido de modo mais amplo pelos pesquisadores. Segundo Gomes (2004), a escrita de si seria um gênero que abarca diários, correspondências, biografias e autobiografias, entendendo-se, essas últimas, como memórias ou como entrevistas de história de vida. Além disso, a autora vê as memórias, as autobiografias, os diários e as cartas como alguns dos componentes da escrita auto-referencial ou escrita de si que integram o que se convencionou chamar de produção de si, isto é, um conjunto de práticas culturais das sociedades ocidentais, constituídas especialmente a partir do século XVIII, ligadas à difusão da leitura e da escrita e, sobretudo, à emergência do indivíduo moderno nessas sociedades.

As considerações de Jean Starobinski (1970) possibilitam ampliar o conceito da escrita autobiográfica para além da ideia de biografia de uma pessoa escrita por ela própria, e parece-nos possível, a partir delas, de fato abranger escritos tais como os diários e as cartas acima mencionados. Para o autor, há três condições essenciais para a escrita autobiográfica: a identidade entre autor e herói da narração (personagem principal), a presença de uma narração, e não de uma descrição ${ }^{1}$, e a cobertura, pela narrativa, de uma sucessão temporal suficiente para que apareça o traçado de uma vida. Dentro de tais condições, o autobiógrafo pode escrever uma página ou vários volumes; contaminar a narrativa de sua vida pelos acontecimentos dos quais foi testemunha distante; datar, com precisão, os momentos de sua narração; fazer um exame de consciência no momento em que escreve; escolher diversos estilos particulares, de modo que não há estilo ou forma obrigatórios para a escrita autobiográfica. Contudo, o estilo, realização do indivíduo, só poderá se afirmar

\footnotetext{
${ }^{1}$ As palavras descrição e narração apresentam vários significados, segundo o Dicionário Houaiss da Língua Portuguesa (HOUAISS; VILLAR, 2001). Aqueles que nos parecem mais pertinentes no contexto do estudo de Starobinski (1970) são o de descrição como "representação oral ou escrita de" ou "exposição"; o de narração como "narrativa", ou seja, "exposição de um acontecimento ou de uma série de acontecimentos mais ou menos encadeados, reais ou imaginários, por meio de palavras ou de imagens".
} 
diante das condições gerais referidas anteriormente. Assim, o estilo da escrita autobiográfica pode ser definido como a maneira própria segundo a qual cada autobiógrafo satisfaz essas condições (que requerem apenas a narração verídica de uma vida, e deixam ao escritor o cuidado de regrar sua modalidade particular, seu tom, ritmo, extensão etc.). Starobinski completa suas considerações acerca do estilo, indicando a indissociabilidade entre a narração e o estilo na constituição da escrita autobiográfica:

Nessa narrativa em que o narrador toma como tema o próprio passado, a marca individual do estilo se reveste de uma importância particular, pois à autorreferência explícita da própria narração, o estilo acrescenta o valor auto-referencial implícito de um modo singular de elocução (STAROBINSKI, 1970, p. 84).

Consideremos, entretanto, outras possibilidades de acepção mais ampla do conceito de escrita autobiográfica. A cultura escrita se tornou, com o passar dos séculos, um componente dominante da maior parte das sociedades humanas, essencial a seu funcionamento e à inserção das pessoas em tais sociedades; em decorrência disso, convivemos intensamente com práticas daquilo que Artières (1998) identifica como arquivamento da vida de cada um.

Pois, por que arquivamos nossas vidas? Para responder a uma injunção social. Temos assim que manter nossas vidas bem organizadas, pôr o preto no branco, sem mentir, sem pular páginas nem deixar lacunas. O anormal éo sem-papéis. O indivíduo perigoso é o que escapa ao controle gráfico. Arquivamos portanto nossas vidas primeiro em resposta ao mandamento "arquivarás tua vida" - e o farás por meio de práticas múltiplas: manterás cuidadosamente e cotidianamente o teu diário, onde toda noite examinarás o teu dia; conservarás preciosamente alguns papéis colocando-os de lado numa pasta, numa gaveta, num cofre: esses papéis são a tua identidade; enfim, redigirás a tua autobiografia, passarás a vida a limpo, dirás a verdade (ARTIÈRES, 1998, p. 21 - 22).

Philippe Artières adverte sobre um aspecto fundamental do arquivamento de nossa vida: ele não é realizado ao acaso, já que sempre fazemos acordos com a realidade, manipulamos a existência, omitimos, rasuramos, riscamos, grifamos, enfatizamos passagens. Enfim, das várias práticas de arquivamento 
do eu, sobressai-se o que se poderia denominar uma intenção autobiográfica. Segundo Artières (1998, p. 22), "o caráter normativo e o processo de objetivação e de sujeição que poderiam aparecer a princípio, cedem na verdade o lugar a um movimento de subjetivação". Assim, arquivar a própria vida é "se pôr no espelho, é contrapor à imagem social a imagem íntima de si próprio, e nesse sentido o arquivamento do eu é uma prática de construção de si mesmo e de resistência" (ARTIÈRES, 1998, p. 22). As práticas de arquivamento da própria vida são parte do movimento nomeado por Foucault (2010)como a preocupação de si, o cuidado de si.

As elaborações de Artières conduzem, pois, a mais uma ampliação na concepção de escrita autobiográfica, visto que, além das formas mais comumente lembradas dessa escrita - as memórias, as cartas e os diários -, somos levados a pensar, também, nos acervos e arquivos pessoais, que podem incluir fotografias, livros, cadernos, documentos e outros objetos, como uma forma de escrita autobiográfica.

Ângela de Castro Gomes (2004), de modo similar a Artières, se refere a práticas culturais diversificadas de produção de si, que envolvem desde a escrita propriamente dita - autobiografias e diários - até a constituição de uma memória de si, realizada pelo recolhimento de objetos materiais, com ou sem a intenção de compor uma coleção. Gomes assinala, também, que a guarda de registros que materializem a história do indivíduo e dos grupos a que pertence, assim realizada, se dá por meio de atos biográficos, nos quais "os indivíduos e os grupos evidenciam a relevância de dotar o mundo que os rodeia de significados especiais, relacionados com suas próprias vidas, que de forma alguma precisam ter qualquer característica excepcional para serem dignas de ser lembradas" (GOMES, 2004, p. 11).

Como se desenvolveram historicamente as práticas de escrita autobiográfica? Decerto não seria possível descrever ou conhecer inteiramente esses processos no mundo ocidental, mas uma breve abordagem de algumas formas e práticas de escrita autobiográfica no passado, talvez possa contribuir para que aprofundemos nossa compreensão do assunto.

\section{Escrita autobiográfica no decorrer do tempo}

É imprescindível assinalar a presença da escrita autobiográfica desde a antiguidade. Entre os tipos de escritos autobiográficos, enumerados anteriormente, destacam-se, sobretudo, as cartas, já que muitas foram 
preservadas e constituem documentos históricos indubitavelmente importantes. A relevância desse tipo de escrito pode ser exemplificada mediante as treze cartas da correspondência de Platão (427-347 a. C.) com seus amigos ou discípulos no mundo helênico que chegaram até nós. No conjunto das cartas, a que se conhece como a sétima, redigida no ano 353 a. C., e dirigida aos amigos e parentes de Dion de Siracusa ${ }^{2}, \operatorname{logo}$ depois de sua morte, oferece interesse especial quando se considera a questão da escrita autobiográfica no sentido estrito de narração da própria vida. De fato, na carta, Platão recapitula acontecimentos de seu passado, especialmente aqueles relacionados à sua participação na vida política de Siracusa. Embora a carta contenha também uma digressão filosófica, na qual Platão expõe a seus correspondentes uma parte de sua teoria do conhecimento, a maior parte do texto é composta por trechos que contam passagens da vida do autor, o que, segundo Nunes (1973), contrasta com o teor de toda a sua obra filosófica. À guisa de ilustração dessa característica, citamos alguns trechos da carta sétima, nos quais se pode observar, desde logo, o uso da primeira pessoa do singular, caracterizador da auto-referência platônica.

"Por ocasião de minha primeira viagem a Siracusa, eu poderia ter quarenta anos..." (PLATÃO, 2007, p. 161)

"Quando moço, aconteceu comigo o que se dá com todos: firmei o propósito, tão logo me tornasse independente, de ingressar na política” (PLATÃO, 2007, p. 161).

"Foram esses os acontecimentos que assinalaram os primeiros tempos da minha visita à Sicília e minha permanência por lá. Depois disso, fiz nova viagem e voltei à Sicília..." (PLATÃO, 2007, p. 168).

"Foi assim que até aquela data eu trabalhei em prol da filosofia e dos meus amigos. A partir de então, vivemos, eu e Dionísio, da seguinte maneira: eu, olhando para fora, como passarinho impaciente de escapar da prisão..." (PLATÃO, 2007, p. 189).

Ainda, no que diz respeito à escrita autobiográfica na antiguidade, um trabalho de Foucault (2010, p. 144) que integra, de acordo com o filósofo, "uma série de estudos sobre as "artes de si mesmo", ou seja, sobre a estética da

\footnotetext{
${ }^{2}$ Dion (408-354 a.C), cunhado de Dionísio I, tirano de Siracusa, exerceu o poder na cidade intermitentemente no período entre 357 e 354 a.C. Tendo feito amizade com Platão quando da primeira visita do filósofo a Siracusa (386 a. C), Dion convidou Platão a voltar à cidade uma segunda vez, vinte anos depois, para educar o jovem tirano Dionísio II na aplicação de seus princípios filosóficos. Platão ainda esteve em Siracusa uma terceira vez, e escreveu a sétima carta após ter voltado à Grécia. A carta data de depois do assassinato de Dion por Calipo (NUNES, 1973).
} 
existência e o domínio de si e dos outros na cultura greco-romana, nos dois primeiros séculos do império", considera que a escrita como treinamento de si, dos séculos I e II, se localiza em duas formas também utilizadas para outras finalidades: os hypomnemata e a correspondência.

A primeira forma se refere a "livros de contabilidade, registros públicos, cadernetas individuais que serviam de lembrete", os quais passaram a ser usados como guias de conduta, contendo "citações, fragmentos de obras, exemplos e ações que foram testemunhadas ou cuja narrativa havia sido lida, reflexões ou pensamentos ouvidos ou que vieram à mente" (FOUCAULT, 2010, p. 147). Foucault vê tais escritos como uma "memória material das coisas lidas, ouvidas ou pensadas"; como "matéria prima para a redação de tratados mais sistemáticos" e, ainda, como "material para ler, reler, meditar, conversar consigo mesmo e com outros" (FOUCAULT, 2010, p. 147-148). Para o filósofo, os hypomnemata são, assim, exercícios de escrita pessoal.

A segunda forma concerne à carta, texto por definição destinado a outro, mas, também um exercício pessoal, que, ainda segundo Foucault, age sobre aquele que a envia, assim como, pela leitura e releitura, sobre aquele que a recebe. A missiva é, portanto, simultaneamente "um olhar que se lança sobre o destinatário (pela carta que recebe, se sente olhado) e uma maneira de se oferecer ao seu olhar através do que é dito sobre si mesmo" (FOUCAULT, 2010, p. 156).

Entretanto, Foucault considera que os primeiros desenvolvimentos históricos do relato de si não devem ser procurados nos hypomnemata, cujo papel é possibilitar a constituição de si a partir da colheita de discursos alheios, e, sim, na correspondência com outrem e na troca de assistência espiritual. A análise foucaultiana se detém, entre outros exemplos, sobre as cartas de Sêneca (4 a.C.-65) a Lucílio ${ }^{3}$, sobre a correspondência de Plínio 4 e a de Marco Aurélio (121-180), e acentua a compreensão da carta como mais do que um adestramento de si mesmo pela escrita, mediante os conselhos e advertências enviados ao outro. A carta, na qual Foucault dá atenção especial às notícias sobre a saúde e aos relatos do dia-a-dia, presentifica o autor para o destinatário, e se constitui, igualmente, um modo de se manifestar para si mesmo e para outros. Mais do que uma introspecção que contribui para o deciframento de si, a carta representa

\footnotetext{
${ }^{3}$ Não se conhece a data de nascimento de Gaio Lucílio Júnior, natural de Pompeia, que foi procurador do império romano na Sicília. Pelas cartas de Sêneca, é possível saber que Lucílio era um pouco mais novo que seu correspondente (CAMPOS, 1991).

${ }^{4}$ Trata-se de Plínio, o Jovem (c. 61-113). (Datas de acordo com o Dictionnaire des auteurs de tous les temps et tous les pays Paris: Laffont, 1989).
} 
uma abertura sobre si mesmo que se oferece ao outro. No relato epistolar de si mesmo, diz o filósofo, "trata-se de fazer coincidir o olhar do outro e aquele que se lança sobre si mesmo ao comparar suas ações cotidianas com as regras de uma técnica de vida" (FOUCAULT, 2010, p. 162). Para ilustrar os comentários de Foucault, recorremos a trechos extraídos de uma passagem da Carta 83, na qual Sêneca fala de sua própria saúde e relata a Lucílio como passou o seu dia.

Queres que eu te descreva integralmente tudo quanto faço em cada dia, de manhã à noite. Quer isto dizer que fazes um bom juízo a meu respeito, pois não imaginas que eu possa ter algo a esconder-te. É assim mesmo que nós devemos viver: como se a nossa vida decorresse à vista de todos. É assim mesmo que nós devemos pensar: como se alguém pudesse surpreender o mais íntimo pensamento. [...] Vou, portanto, fazer o que me pedes: descrever-te com todo o gosto cada acto que pratico, e por que ordem o faço. Vou observar-me com toda a atenção, vou fazer uma coisa da maior utilidade: avaliar com cuidado cada um dos meus dias. [...]

$\mathrm{O}$ meu dia de hoje pertence-me, ninguém me roubou um bocadinho que fosse: todo ele foi dividido entre o leito ${ }^{5}$ a leitura. Os exercícios físicos ocuparam uma parcela mínima. A propósito, devo render graças à velhice que me não faz perder muito tempo com tais exercícios! Um pouco de movimento, e fico cansado; ora o cansaço obriga mesmo os melhores atletas a darem por terminado o treino (SÊNECA, 1991, p. 369-370).

No entanto, na antiguidade, vamos encontrar também registros de desinteresse ou até mesmo rejeição à ideia da narração de si: Porfírio (232304), discípulo do pensador neoplatônico Plotino (c.205-270), em sua Vida de Plotino, salienta que seu mestre não suportava falar nem de sua raça, nem de seus pais, nem de sua pátria, recusando-se terminantemente a posar para que seu retrato fosse pintado e nunca tendo revelado a ninguém sua data de nascimento. Porfírio acentua a concentração mental de Plotino e suas dificuldades para escrever suas meditações. Conquanto, nas conversas com Porfírio, Plotino lhe tenha relatado alguns acontecimentos de sua vida, não há textos

\footnotetext{
${ }^{5}$ De acordo com o tradutor da edição que consultamos, não se deve entender dessa passagem que o filósofo passou o dia a dormir, pois ele necessitava de pouco sono. O leito referido por Sêneca seria uma espécie de divã em que ele se reclinava para meditar quando não estava lendo ou escrevendo em sua mesa de trabalho (CAMPOS, 1991).
} 
autobiográficos de Plotino (PORFÍRIO, 1992). O modo como o discípulo o descreve nos conduz a percebê-lo mais como um adepto da negação de si do que como avesso a narrar-se aos outros.

Pertence aos tempos antigos uma das obras mais célebres da escrita autobiográfica, as Confissões de Santo Agostinho (354-430), produzidas em torno do ano 400, quando o autor já era há cinco anos o bispo de Hipona ${ }^{6}$. De acordo com Starobinski (1970), nesse livro, enquanto Deus é o destinatário direto do discurso proferido por Agostinho, os homens, admitidos como testemunhas da confissão e nomeados na terceira pessoa, são beneficiários indiretos das efusões apresentadas. A invocação a Deus, todavia, não é somente um artifício retórico. Deus, onisciente, capaz de enxergar todos os tempos em uma só visada, não precisa receber a narrativa de Agostinho; ele só é o interlocutor das confissões no momento em que elas são feitas porque é o mestre de toda a experiência anterior do autor. Tomando Deus tão ostensivamente como interlocutor, Agostinho se dedica à veracidade absoluta, já que não poderia, diante dele, falsificar ou dissimular qualquer coisa. Assim, em virtude de seu destinatário, a escrita autobiográfica agostiniana não corre o risco da falsidade. Observe-se, porém, alerta Starobinski, que a sequência e o encadeamento dos acontecimentos no texto de Agostinho são realizados para o leitor humano, encarregado de legitimar a discursividade da confissão. Conciliam-se, na obra, a motivação edificante e a finalidade transcendente da confissão: a palavra dirigida a Deus poderá converter e reconfortar outros homens.

Starobinski chama a atenção, também, para um elemento importante a motivação para a escrita autobiográfica de Agostinho: não teria havido razão para as confissões se não tivesse intervindo, na vida anterior do autor, uma modificação radical: a sua conversão. No caso da obra agostiniana, é fundamental ressaltar que a transformação interior do escritor e o caráter exemplar dessa mesma transformação oferecem a matéria para um discurso narrativo que tem o eu como sujeito e objeto.

Embora não haja dúvida quanto à existência de muitos outros escritos autobiográficos, produzidos no transcorrer das idades antiga e medieval, e às muitas possibilidades de se tecerem comentários acerca deles, passamos, agora, a abordar a idade moderna, em que, graças à entrada inexorável das sociedades ocidentais na cultura escrita, se ampliará o espaço para a escrita auto-referencial. Chartier (1986) refere-se ao fato de Philippe Ariès, coordenador do seminário intitulado A propos de l'histoire de l'espace privé, realizado em 1983, ter

${ }^{6}$ Conforme o Dictionnaire des Oeuvres de tous les temps et de tous les pays. Paris: Laffont, 1989. 
apontado os progressos da alfabetização, o crescimento da circulação do escrito, impresso ou manuscrito, e a difusão da prática da leitura silenciosa como transformações decisivas, ocorridas na Europa entre os séculos XVI e XVIII, as quais traçaram, de modo inédito, a fronteira entre os gestos culturais do foro privado e da vida coletiva. Chartier assinala, a partir da proposição de trabalho de Ariès no referido colóquio, como as novas modalidades de relação com a escrita, nessa época, construíram uma esfera de intimidade que representou, ao mesmo tempo, uma retirada e um refúgio para o indivíduo subtraído aos controles da comunidade. Ainda que não igualmente distribuídas geográfica e socialmente, as mudanças operadas incluíam o crescimento do número de pessoas que sabiam ler e escrever, configurando-se, então, o desenvolvimento da familiaridade com o escrito e a aquisição de competências culturais que, antes, eram privilégio de uma minoria. $\mathrm{O}$ autor ressalta que o saber ler foi a condição obrigatória para o aparecimento de práticas novas, constitutivas da intimidade individual. Desse modo, apesar de o desenvolvimento da alfabetização e a difusão da leitura não terem sido homogêneos nos diversos ambientes e classes sociais europeus do período moderno, eles contribuíram definitivamente para modificar a ideia que o homem ocidental faz de si próprio e de sua relação com os outros.

Na escrita autobiográfica, a partir do século XVI, têm lugar importante as memórias, escritas pelos representantes mais eminentes da elite social, particularmente os políticos e militares. De acordo com Goulemot (1986), nessas obras, os autores que, quase sempre, tomam parte na história pública, assumem e justificam seu papel de testemunhas ou atores. Trata-se, no entanto, de memórias que se detêm no ponto em que começa o privado e o íntimo, e que excluem da escrita tudo que não se vincula à vida pública. Goulemot comenta que esses textos deixam entender que o privado e o íntimo não existem ou, se existem, são desprovidos de interesse e interditados ao discurso. Ou seja, há uma intimidade que não é da ordem do dizível e do escrito. Mesmo com a valorização exclusiva da vida pública, essas memórias revelam a importância do sujeito individual às expensas da coletividade. $\mathrm{O}$ autor acrescenta que o acento posto no sujeito, à custa do coletivo, aparece, ainda com mais força, nos diários pessoais, na medida em que, se não visam a engrandecer seu autor, ou a defender sua causa, eles mostram a consciência de neles se dizer aquilo que escapa aos demais papéis escritos.

Contudo, é ainda no decurso do século dezoito que uma obra tornada célebre na posteridade ${ }^{7}$ demarcará a ultrapassagem da linha que interdita a

\footnotetext{
${ }^{7}$ Peter Gay (1999, p. 122-124) comenta detalhadamente a repercussão do livro de Rousseau entre leitores do século XIX, destacando a percepção desses leitores quanto ao caráter moderno das confissões.
} 
intimidade nos escritos autorreferenciais - trata-se das Confissões de JeanJacques Rousseau (1712-1778), trabalho póstumo publicado em duas partes: os seis primeiros livros, em 1782, e os seis últimos, em $1789^{\circ}$. O que diferencia, essencialmente, a obra rousseauniana em relação às memórias anteriores, caracterizadas pela exposição do público e pelo silenciamento do privado, reside na ênfase nessa segunda dimensão. Goulemot (1986) sublinha a mutação representada por essa autobiografia, constituída contra a escrita aristocrática das memórias tradicionais.

Não apenas o eu e sua história constituem o assunto da narrativa autobiográfica, mas o acento é colocado sobre o eu íntimo e secreto. A barreira entre vida privada e vida pública não existe mais aqui. O privado se exibe. Trata-se mesmo de compreender a razão de ser do eu profundo, além da aparência social e dos hábitos. Buscam-se os acontecimentos fundadores que explicam o porquê de uma personalidade. Levantam-se as máscaras, descartam-se as mentiras. Rousseau refere os atos de fundação, registra as constantes (GOULEMOT, 1986, p. 401).

Mais do que simplesmente expor o íntimo e o secreto, porém, a obra de Rousseau tomará o leitor como testemunha da sinceridade do autor. Com efeito, o primeiro período do Livro I da versão estabelecida para o manuscrito de Genebra das Confissões ${ }^{9}$ acentua a originalidade da realização e invoca esse leitor-testemunha: "Meu empreendimento não teve predecessores e sua execução não terá imitadores. Quero mostrar a meus semelhantes um homem em toda a verdade da natureza, e esse homem será eu"10. Starobinski (1970), ao chamar a atenção para o fato de que Rousseau, como Santo Agostinho, se dirige a Deus, comenta que, mesmo requerendo, ainda como Agostinho, a presença de Deus para garantir a veracidade de sua proposta ${ }^{11}$, o filósofo o faz somente no início. Starobinski assinala a presença difusa, nas Confissões, do leitor, com quem Rousseau se envolve, por vezes, num diálogo fictício, esforçando-se por convencê-

\footnotetext{
${ }^{8}$ De acordo com a edição das Confissões de Rousseau por Bernard Gagnebin e Marcel Raymond (ROUSSEAU, 2010).

${ }^{9}$ De acordo com a edição das Confissões que consultamos, há três manuscritos da obra na caligrafia de Rousseau - o de Genebra, o de Paris e o de Neuchâtel, os quais contêm variantes importantes. O manuscrito de Genebra deu origem à edição que utilizamos (ROUSSEAU, 2010).

${ }^{10}$ Uma versão ligeiramente diferente dos parágrafos iniciais do Livro I das Confissões pode ser encontrada no endereço http://www.autopacte.org/ sob o título Préambule du texte définitif (Acesso em: 06 dez. 2010).

11 "Que a trombeta do juízo final soe quando quiser: virei com este livro nas mãos me apresentar diante do juiz supremo" são também palavras integrantes do início das Confissões.
} 
lo da veracidade absoluta de sua narrativa, assim como da inocência de suas intenções. Que a relação com Deus tenha esmaecido, quando comparada ao que ocorre na relação imediata que prevalece em Agostinho, não afeta o estatuto de veracidade, buscada sob a consideração do sentimento íntimo, na instantaneidade da emoção comunicada à escrita. Assim, reforça Starobinski, a alocução a um destinatário transcendente, que caracteriza o discurso de Agostinho, é substituída, no texto rousseauniano, pelo pathos da expressão fiel. A absoluta autenticidade da narração é assegurada pela espontaneidade da escritura, calcada sobre a espontaneidade do sentimento no momento da confissão. O estilo, no próprio dizer de Rousseau, toma assim uma importância que não se limita mais à disposição da linguagem, à procura técnica dos efeitos: ele se torna enfaticamente auto-referencial e pretende remeter, inevitavelmente, à verdade interior do autor. Nesse sentido, é oportuno lembrar a epígrafe com que principiam as Confissões: Intus et in cute, cuja tradução literal seria no interior e sob a pele $^{12}$. Uma tradução expressiva poderia ser nas profundezas e na superfície.

O século XIX consagrará definitivamente a escrita autobiográfica: Peter Gay (1999) sublinha a grande intensidade da preocupação dessa era com o eu, particularmente entre os homens e mulheres das classes médias. De acordo com o autor, os escritores - romancistas, poetas, editorialistas - e os artistas pintores, escultores e compositores - difundiram entre os leitores dessas camadas da população europeia o culto do autoconhecimento. O chamado burguês comum aderiu, então, à peregrinação ao mundo interior, com cartas confidenciais, diários pessoais, confissões escritas, missivas de amor e textos com reflexões de caráter religioso. Ainda segundo Gay (1999. p. 14), o que torna importante o auto-escrutínio nos homens e mulheres do século XIX "não é o fato de terem inventado a introspecção ou de terem sido os primeiros a refletirem sobre ela, mas a circunstância de a haverem oferecido, quase obrigatoriamente, a um público mais amplo". O historiador enfatiza, assim, o interesse dos leitores pela escrita auto-referencial, e, também, o crescimento da circulação desses escritos, destacando-se as memórias e autobiografias.

Ademais, para Peter Gay, ainda que existissem distâncias e diferenças nas aspirações sociais dos burgueses que compunham a maior parte dos devotados ao cultivo do eu interior pela via da escrita, pois entre eles estavam, ao mesmo tempo, barões da indústria, pequenos funcionários bancários, comerciantes, profissionais liberais, professores, proprietários de terras e de lojas, todos compartilhavam um modo de pensar sobre si mesmos. Gay sublinha que a

\footnotetext{
${ }^{12}$ Segundo Catherine Koenig (ROUSSEAU, 2010), essas palavras pertencem ao poeta romano Pérsio (34-62).
} 
diversificada burguesia do Oitocentos era uma minoria distinta e reconhecível, cuja ideologia consistia não apenas na frugalidade, na pontualidade e na autodisciplina, mas, também, em um compromisso com a honestidade interior que conduzia a tornar transparente sua vida íntima.

No século XIX, acentua o autor, "as auto-biografias e os auto-retratos, as biografias, os romances e obras históricas sobre o caráter das pessoas adquiriam a força de consideráveis indústrias domésticas,", e "os diários e a correspondência íntima se tornaram mais comuns e mais reveladores do que nunca" (GAY, 1999, p. 16).

Ângela de Castro Gomes situa o entendimento das práticas culturais de produção de si, que englobam tanto essas obras de escrita propriamente dita quanto a guarda de objetos materiais com o intuito de registrar a história das pessoas, na emergência do indivíduo moderno nas sociedades ocidentais. Essa autora destaca a transformação das sociedades ditas tradicionais no sentido de uma lógica coletiva, regida pela tradição, deixar "de se sobrepor ao indivíduo, que se torna "moderno" justamente quando postula uma identidade singular para si no interior do todo social, afirmando-se como valor distinto e constitutivo desse mesmo todo" (GOMES, 2004, p. 11-12). Nas sociedades modernas, a vida individual adquire uma importância antes desconhecida, e se torna "matéria digna de ser narrada como uma história que pode sobreviver na memória de si e dos outros" (p. 12).

Esse longo e complexo processo de transformação, que levou à consolidação e cada vez maior ampliação das várias práticas de escrita autobiográfica, sobretudo no século XIX, manteve-se em curso durante todo o século XX e no início do século atual, período em que são inúmeras as publicações de memórias, diários, autobiografias, correspondências, mesmo com o impacto das enormes mudanças nas comunicações, com a utilização cada vez maior da telefonia e da internet. Aliás, essas mudanças trazem consigo novas práticas de escrita autobiográfica, como as mensagens eletrônicas e os blogs, dos quais têm se ocupado pesquisadores do tema, como Philippe Lejeune (2008).

Vamos nos valer de dois fragmentos de escritos autobiográficos, publicados no século XX, com referências a passagens da vida dos autores situadas no final do século anterior para apresentar, agora, o interesse principal que nos dirige para o estudo da escrita autobiográfica.

Aos onze anos, comecei a estudar Euclides, tendo meu irmão como tutor. Foi esse um dos grandes acontecimentos de minha vida, tão deslumbrante como o primeiro amor. Eu 
não imaginara que houvesse no mundo nada tão delicioso. Após haver aprendido a quinta proposição, meu irmão me disse que ela era, em geral, considerada difícil, mas eu não encontrara dificuldade alguma. Foi essa a primeira vez que me ocorreu que eu talvez pudesse ser dotado de certa inteligência. A partir de então, até o momento em que Whitehead e eu terminamos o nosso trabalho, Principia Mathematica, quando eu contava trinta e oito anos de idade, a matemática tornou-se o meu principal interesse, bem como a minha principal fonte de felicidade. Como toda felicidade, porém, ela não foi uma felicidade absoluta. Haviam-me dito que Euclides provava as coisas, e foi grande desapontamento, para mim, que ele começasse com axiomas. A princípio, recusei-me a aceitá-los, a menos que meu irmão me desse alguma razão pela qual eu devesse fazê-lo, mas ele me disse: "Se você não os aceitar, não podemos prosseguir" e, como eu desejava prosseguir, admiti-as, relutantemente, pro tem. A dúvida quanto às premissas da matemática, que senti naquele momento, permaneceu comigo, determinando o curso de minha obra subseqüente (RUSSELL, 1967, p. 32).

1895

13 de novembro

Volto da Escola ajuizada e com tenção firme de ficar em casa estudando. Mamãe tem toda a razão. Estou mesmo muito vadia.

Mas entro para o quarto, abro o livro, olho as lições e fico pensando comigo: "Eu sei que faço os exames e hei de passar no segundo ano como passei no primeiro. Para que é que se inventou cola? Passei pela escola primária da mestra Joaquininha, que é uma das boas da Diamantina, e nunca me ensinaram física, geometria nem nada disso. Para ensinar menino burro a ler, meu preparo é suficiente. Para que ficar em cima dos livros fazendo uma coisa tão aborrecida, quando posso estar no Jogo da Bola me divertindo na companhia dos primos? Fiquem mamãe e Luizinha fazendo da vida delas sofrimento; eu vou aproveitar a minha" (MORLEY, 1958, p. 255).

10 de dezembro

No exame de geometria fui tão feliz que me parece até um sonho! 
Catãozinho é outro professor meu amigo. Até me atrapalha a vida porque acha graça na minha vadiação e nunca me obriga a estudar. [...] Catãozinho e os outros me dizem: "Não precisa estudar não; fica aí. Nós te levamos às nove horas." Voltando ao exame. Na prova escrita Clélia me deu o borrão dela e eu copiei. Na oral, nos quinze minutos que temos, Clélia me levou para o canto do outro salão e disse: "Helena, preste atenção, pelo amor de Deus, estes quinze minutos, que você faz um exame bom." Explicou-me os teoremas com tanta clareza, que da segunda vez eu repeti para ela muito bem.

Fui para a pedra. Catãozinho me conhecendo muito bem e sabendo que eu me fio só na memória disse: "Você quer que eu lhe faça perguntas ou quer expor o ponto?" Respondi que preferia expor e expus, um atrás do outro, os três teoremas, sem ele dizer uma palavra. Acabada a exposição, ele virou para os outros examinadores e disse: "Eu estou satisfeito. Vocês querem fazer alguma pergunta?" Eles responderam que não. Saí radiante.

À noite, na casa de dona Gabriela, Catãozinho me disse: "Olhe, eu não lhe dei distinção porque você é muito vadia durante o ano. Mas não pude deixar de lhe dar plenamente. Está satisfeita?"

Que é que eu havia de responder? (MORLEY, 1958, p. 263 264).

Os fragmentos que se acabou de ler são textos nos quais se evidenciam duas experiências de educação matemática no final do século XIX: o primeiro é um trecho extraído da autobiografia de Bertrand Russell (1872- 1970), herdeiro da aristocracia inglesa da era vitoriana, enquanto os dois outros são extratos do diário de Helena Morley, pseudônimo de Alice Dayrell Caldeira Brant (18801970), uma menina brasileira, nascida e criada em Diamantina/Minas Gerais, cuja família viveu, em sua infância e adolescência, enormes dificuldades econômicas. Percebe-se, na leitura, que além do ponto comum da referência a experiências vividas pelos autores nas décadas finais do Oitocentos, pois Russell faz um relato referente a 1883, quando tinha onze anos, e Morley registra eventos de 1895, quando tinha quinze anos, os textos têm em comum a menção ao estudo da geometria. São, porém, duas experiências totalmente díspares em relação ao aprendizado da geometria, pois, se Russell narra sua introdução a Euclides como "um dos grandes acontecimentos" de sua vida, "tão deslumbrante 
como o primeiro amor", dizendo que não imaginara haver no mundo "nada tão delicioso", e prossegue dizendo que, a partir dela, a matemática se tornou o seu principal interesse, Helena confessa preferir se divertir "na companhia dos primos" a "ficar em cima dos livros fazendo uma coisa tão aborrecida" quanto estudar, e considera que estudar geometria não é necessário a alguém que vai "ensinar menino burro a ler".

Enquanto Bertrand Russell estudava sob a supervisão de seu irmão sete anos mais velho, em casa, Helena Morley frequentava o segundo ano da Escola Normal de Diamantina, para se habilitar a lecionar como professora primária. Os fragmentos nos dizem mais, pois Russell fala, ainda, de sua decepção com Euclides, que começava com axiomas, quando ele esperava que tudo fosse provado, e assinala que sua dúvida quanto às premissas da matemática, sentida naquele momento, determinaria o curso de seu trabalho, ao passo que Helena relata um episódio de êxito em exames, fundamentado em boas relações de amizade com o professor, na cópia da prova escrita de sua amiga e na memorização de teoremas com o auxílio dessa mesma amiga.

Mais do que contrastar duas experiências diferentes de educação matemática, de uma mesma época em realidades completamente distintas, os textos aqui citados, e brevemente comentados, nos servem para chamar a atenção para a possibilidade de estabelecer interlocuções entre a escrita autobiográfica e a história da educação matemática. Todavia, para propor projetos de investigação que empreendam esse tipo de diálogo será importante retomar e ampliar nossa discussão inicial acerca dos escritos autobiográficos, detendo-nos um pouco mais em sua conceituação e tipologia.

\section{Sobre o conceito e os tipos de escritos autobiográficos}

Embora reconhecendo as dificuldades de tal tarefa, pelo desafio de fixar os limites da escrita autobiográfica e elaborar uma classificação dos escritos auto-referenciais, válida para épocas e lugares distintos, Antonio Viñao (2000, 2004) procura estabelecer uma categorização para esses escritos. Alertando para o fato de que, o que se considera autobiografia, memórias, carta, diário, livro ou caderno com anotações e recortes etc., é algo que se modifica no espaço e no tempo, muitas vezes não correspondendo à sua denominação formal, o autor enumera alguns tipos de escritos autobiográficos: as autobiografias e memórias, as entrevistas autobiográficas, os diários, os auto-retratos.

As autobiografias e memórias, em sentido estrito (confissões, 
recordações, testemunhos, impressões etc.), são textos que narram vidas, independentemente de um caráter mais ou menos pessoal, íntimo, profissional ou público. Já as entrevistas autobiográficas, provenientes de depoimentos gravados ou taquigrafados, constituem uma modalidade próxima ou precursora da história oral. Os diários são uma sucessão de textos mais ou menos extensos, com maior ou menor frequência ou regularidade, ao longo de um período determinado. Entre os diários, há os pessoais e os profissionais (para os professores, podem ser, por exemplo, os de preparação de aulas; os diários de classe, de registro das atividades de sala de aula; os de prática, em forma de memória do acontecido). O auto-retrato é um texto breve, independente ou integrado a outro mais amplo, circunscrito à descrição dos traços físicos e psicológicos de quem escreve.

Antonio Viñao $(2000,2004)$ considera, ainda, as agendas, a correspondência, os arquivos pessoais e as folhas de méritos e serviços, que seriam uma espécie de Curriculum vitae comentado.

As formas autobiográficas mais comumente evocadas, as autobiografias e memórias, são amiúde distinguidas do seguinte modo: na autobiografia, o centro da atenção é o eu que recorda e dá conta de sua vida e sua pessoa, ao passo que, nas memórias, o que prepondera não é o eu que recorda e narra, mas, sim, o mundo exterior, os acontecimentos e personagens que são recordados e dos quais se fala. Assim, as memórias tenderiam a ser uma cosmo-representação, e a autobiografia uma auto-representação. Contudo, como Viñao e outros autores indicam, essa distinção é de natureza mais teórica e acadêmica do que conceitual, uma vez que, o mais comum, é a combinação, em um mesmo texto, de ambos os aspectos, e o uso indiferente, nos títulos, de um ou outro dos termos. Na verdade, é impossível à narrativa "restringir-se à focalização do $e u$ que narra", pois este, "ao desencadear a retrospecção, olha não apenas para si e para outros eus que com ele interagiram, e com os quais estabeleceu relações recíprocas, mas também para um determinado contexto histórico-geográfico, que pode ser objeto de maior ou menor atenção" (MIRANDA, 1992, p. 37).

Entre os muitos pesquisadores que se têm debruçado sobre a escrita autobiográfica, frequentemente citado nos textos que abordam a temática, um nome de destaque é o do francês Philippe Lejeune, que, desde a publicação de seu primeiro livro, L'autobiographie en France, em 1971, tem produzido ensaios teóricos e análises sobre a expressão autobiográfica. As elaborações de Lejeune nos parecem férteis para qualquer estudo sobre a escrita autobiográfica, e, por isso, aqui apresentamos uma breve discussão dos pontos que nelas se nos afiguram como centrais. $\mathrm{O}$ primeiro deles refere-se à conceituação inicial do autor para a 
autobiografia. Para estabelecer o corpus que analisaria, em seu primeiro livro, Lejeune propôs a seguinte definição para a autobiografia: "Narrativa retrospectiva em prosa que uma pessoa real faz de sua própria existência, quando focaliza sua história individual, em particular a história de sua personalidade" (LEJEUNE, 2008, p. 14).

Lejeune comenta que sua posição como definidor precisa ser relativizada e explicitada: "historicamente, esta definição não pretende cobrir mais que um período de dois séculos (desde 1770) e só diz respeito à literatura europeia" (LEJEUNE, 2008, p. 14). Ele também explica que essa definição encerra diversos elementos: a forma da linguagem (narrativa em prosa), o assunto tratado (vida individual, história de uma personalidade), a situação do autor (identidade entre autor e narrador), a posição do narrador (identidade entre narrador e personagem principal e perspectiva retrospectiva da narrativa). Lejeune acrescenta, ainda, que, com essa definição proposta inicialmente, para ser uma autobiografia, uma obra deve preencher, de modo simultâneo, todas essas condições. No entanto, ele reconhece que certas condições podem não ser totalmente preenchidas: o texto deve ser principalmente uma narrativa, a perspectiva principalmente retrospectiva (isso não exclui nem seções de auto-retrato, nem diário da obra, nem construções temporais complexas); o assunto deve ser principalmente a vida individual, mas a crônica e a história social ou política também podem ocupar um espaço. Em contrapartida, duas condições não podem falhar, pois são elas que opõem a autobiografia à biografia e ao romance pessoal; essas condições são a situação do autor e a posição do narrador: deve haver identidade entre o autor (cujo nome remete a uma pessoa real) e o narrador, e identidade entre o narrador e o personagem principal. Contudo, a questão da relação de identidade entre autor, narrador e personagem levanta vários problemas, discutidos em detalhe por Lejeune (2008, p. 15 - 44; p. 55 - 56).

Sem nos determos para apresentar ou comentar essa discussão, passemos ao essencial no trabalho de Lejeune. O conceito central de sua obra é o de pacto autobiográfico ${ }^{13}$ - um contrato de leitura entre o autor-narradorpersonagem e o leitor. Esse conceito, que já se apresentava no primeiro livro do pesquisador francês, foi retomado e desenvolvido em seus trabalhos posteriores, publicados em 1975, 1986 e $2005^{14}$. A autobiografia passa a ser, com a proposição

\footnotetext{
${ }^{13}$ Além de nomear o livro de Lejeune publicado no Brasil (LEJEUNE, 2008), o conceito é utilizado no nome e no conteúdo do site mantido pelo autor (disponível em: <http://www.autopacte.org >. Acesso em: 14 dez. 2010). Nesse site, informa-se que Autopacte é o nome de um personagem do ensaísta e moralista francês, Jean de La Bruyère (1645-1696), utilizado por Lejeune para troçar de si mesmo.

${ }^{14}$ Em Lejeune (2008), a primeira parte, intitulada O pacto autobiográfico, inclui três artigos: $O$ pacto autobiográfico, $O$ pacto autobiográfico (bis) e O pacto autobiográfico, 25 anos depois, publicados originalmente em 1975, 1986 e 2005 respectivamente.
} 
da noção de pacto autobiográfico, qualquer texto regido por um tal pacto. Nas palavras de Lejeune, no pacto autobiográfico, "o autor propõe ao leitor um discurso sobre si, mas também uma realização particular desse discurso, na qual a resposta à pergunta "quem sou eu?" consiste em uma narrativa que diz "como me tornei assim"”, (LEJEUNE, 2008, p. 54).

Entretanto, Lejeune adiciona outra dimensão ao pacto autobiográfico: além de referir-se à intenção do autor, aspecto que acabamos de mencionar, ele considera, igualmente, a intenção que o leitor atribui a esse autor. Em outros termos, diz o próprio Lejeune, "imaginei sob a forma de um contrato único um duplo processo: o compromisso e o sistema de apresentação escolhido pelo autor e o modo de leitura escolhido pelo leitor" (LEJEUNE, 2008, p. 57). No que diz respeito ao autor, o pacto seria o compromisso que ele assume de contar diretamente sua vida (ou uma parte, ou um aspecto de sua vida) com um espírito de verdade. O pacto autobiográfico se opõe ao pacto de ficção (ou pacto romanesco). De acordo com Lejeune, o autor de um romance (mesmo se inspirado em sua vida) não nos pede que acreditemos em tudo que conta, mas simplesmente que brinquemos de acreditar.

O autobiógrafo, por outro lado, nos promete que o que vai dizer é verdadeiro, ou pelo menos, é o que ele crê verdadeiro. Ele se comporta como um historiador ou um jornalista, com a diferença que o assunto sobre o qual promete dar uma informação verdadeira é ele mesmo. O compromisso de dizer a verdade sobre si pode ser reconhecido pelo leitor de várias maneiras. Por vezes, pelo título: Memórias, Lembranças, Histórias de minha vida... Por vezes, pelo subtítulo (autobiografia, narrativa, lembranças, diário), e, por vezes, simplesmente pela ausência de menção a romance. Por vezes, há um prefácio do autor, ou uma declaração na quarta capa do livro. Enfim, muito frequentemente, o pacto autobiográfico traz a identidade de nome entre o autor cujo nome está na capa e o narrador-personagem que conta sua história no texto.

Embora o conceito de pacto autobiográfico seja complexo, tenha sido construído a partir de uma referência do final do século XVIII (as Confissões de Rousseau) e comporte necessariamente uma dimensão histórica ${ }^{15}$, ele oferece

\footnotetext{
${ }^{15}$ Lejeune (2008, p. 45-46) chama a atenção para as variações temporais nos códigos presentes nas publicações em épocas distintas: o nome do autor, o título, o subtítulo, o nome da coleção, a editora, a natureza dos prefácios (que, na verdade, segundo o pesquisador, são essenciais ao pacto autobiográfico, já que comandam a leitura) não aparecem do mesmo modo sempre, dependendo ao mesmo tempo das mudanças de atitude de autores e leitores e de questões técnicas ou comerciais da edição. Assim, por exemplo, desde o século XVII, o uso do anonimato e o emprego do pseudônimo se modificaram muito, e os jogos quanto à alegação da realidade nas obras de ficção não são praticados da mesma maneira como o eram no Setecentos. Inversamente, os leitores passaram a apreciar supor a presença do autor mesmo em trabalhos que não parecem autobiográficos.
} 
uma perspectiva mais ampla aos pesquisadores na apreciação de diversos tipos de textos como escrita autobiográfica, possibilitando ultrapassar as autobiografias diretamente encaixadas na definição de Lejeune. Assim, diários, cartas, relatos de vida de diferentes tipos são considerados escritos autobiográficos, desde que neles esteja presente um pacto de verdade. O conceito de pacto autobiográfico permite, ainda, trabalhar com textos orais gravados, tenham sido produzidos para a escrita de uma autobiografia em livro por um redator que não coincide com o personagem central ou como relatos de vida para investigações específicas, como no caso de uso da metodologia da história oral. O próprio Lejeune, quando da produção da segunda edição de L'autobiographie en France, em 1998, afirma ter mantido o texto de 1971 no início do livro, mas lembra ter ampliado o repertório de textos autobiográficos, compondo "uma nova bibliografia, atualizada, que abrange a história oral, os estudos de gênero, os quadrinhos, Internet, tudo que faz parte de nossa época" (LEJEUNE, 2008, p. 76). O autor diz ainda que, se no início dos anos 1970, seu interesse estava em autobiografias de escritores, sua atitude, quinze anos depois, tinha adquirido um caráter de democratização Lejeune passou a se interessar "pela vida de qualquer um e pelas formas mais elementares e também mais comuns do discurso e da escrita autobiográfica" (LEJEUNE, 2008, p. 66).

Feitas essas considerações acerca dos escritos autobiográficos, pensar em trabalhá-los como fonte ou objeto da história da educação matemática requer discutir alguns aspectos gerais das relações entre escritos autobiográficos, história e historiografia.

\section{Escrita autobiográfica, história e historiografia da educação}

A escrita autobiográfica sempre foi fonte para a historiografia, que se vale, desde muito tempo, de algumas de suas formas, a exemplo da correspondência. Contudo, os diversos tipos dessa escrita adquirem importância crescente com o desenvolvimento, nas últimas décadas, da história social e cultural, ligada à mudança dos objetos, das fontes, da noção de sujeito e da hierarquia dos fatos. Beatriz Sarlo (2007) comenta o deslocamento do olhar dos historiadores e cientistas sociais para fenômenos e acontecimentos como a loucura, a festa, o campesinato, as estratégias do cotidiano, na busca do detalhe oposto à normalização e da subjetividade que se distingue como anômala, ao mesmo tempo em que esse olhar também se desloca para os sujeitos considerados normais, "quando se reconheceu que não só eles seguiam itinerários sociais traçados, como protagonizaram negociações, transgressões e variantes" 
(SARLO, 2007, p. 17). Mudanças de perspectiva para a história não acontecem desacompanhadas de mudanças nas fontes de investigação, e é nesse contexto de "guinada subjetiva", em que se impõe um "reordenamento ideológico e conceitual da sociedade do passado e de seus personagens, que se concentra nos direitos e na verdade da subjetividade" (SARLO, 2007, p. 18), que adquirem valor as fontes autobiográficas, entre as quais se encontram tanto os depoimentos orais quanto os escritos auto-referenciais.

Ao comentar a constituição do individualismo moderno, à qual se vincula diretamente a guarda de registros de memória e a ampliação da produção e da circulação da escrita autobiográfica, Gomes (2004) assinala, como já foi dito, um processo de transformação social ao qual se integra a valorização da memória individual. Tais registros de memória são caracterizados pela autora como documentos escritos a partir da subjetivação e da fragmentação constituintes das feições mais marcantes desse indivíduo comum; ela também alude a seu valor como documentos históricos, em conexão com a noção de verdade nesse contexto sociocultural.

Os registros de memória dos indivíduos modernos são, de forma geral e por definição, subjetivos, fragmentados e ordinários como suas vidas. Seu valor, especialmente como documento histórico, é identificado justamente nessas características, e também em uma qualidade decorrente de uma nova concepção de verdade, própria às sociedades individualistas. Sociedades que separaram o espaço público do privado, a vida laica da religiosa, mas que, em todos os casos, afirmaram o triunfo do indivíduo como um sujeito voltado para si, para sua razão e seus sentimentos. [...]

Na cultura desse tipo de sociedade é que a noção de verdade passa a ter um forte vínculo com as ideias de foro íntimo e de experiência de vida dos indivíduos, ambas marcantes para as definições de conhecimento e ética próprias ao individualismo. A verdade, nesse contexto sociocultural, não mais se esgota em uma "verdade factual", objetiva, una e submetida à prova científica ou jurídica, que continua a ter vigência e credibilidade e que também tece conexões com o individualismo moderno (GOMES, 2004, p. 13).

Assim, a verdade passa a incorporar uma ligação direta com a subjetividade do indivíduo, ganhando uma dimensão fragmentada e impossível de sofrer controles absolutos. Não mais unitária, mas não por isso desprovida de 
consistência, a verdade passa a ser pensada em sentido plural, do mesmo modo como a pluralidade também se encontra nas vidas e memórias individuais. A escrita da história, especialmente a partir das décadas finais do século XX, de várias maneiras e de forma gradativa, se dá a partir da convivência com dois sentidos da ideia de verdade: verdade dos fatos e sinceridade do indivíduo (GOMES, 2004).

Dito de outro modo, estamos diante da "história escrita no plural", em que o interesse é "plural, múltiplo, heterogêneo, disperso"; pensa-se "não mais NA história, mas NAS histórias possíveis, nas versões históricas", que podem ser legitimadas "como verdades dos sujeitos que as vivenciaram e as relatam" (GARNICA, 2008, p. 135).

As diversas formas de escrita auto-referencial têm recebido, recentemente, no Brasil e no contexto internacional, reconhecimento e visibilidade crescentes, tanto no mercado editorial quanto nas instâncias acadêmicas. Ângela de Castro Gomes, ainda que considere que na área da história, no Brasil, ainda não são muitos "os estudos que se dedicam a uma reflexão sistemática sobre esse tipo de escritos" (GOMES, 2004, p. 9), realça que as iniciativas mais frequentes nessa direção se têm dado nos campos da literatura e da história da educação. Nesses domínios, os escritos autobiográficos se vêm constituindo como objetos e fontes de pesquisa, e a atenção a eles tem resultado em diversos trabalhos ${ }^{16}$.

No que concerne à história da educação, Antonio Viñao (2000) indica alguns objetivos que podem ser perseguidos com o uso das fontes autobiográficas: a reconstrução dos processos e modos de educação de uma geração ou grupo social em uma época ou contexto determinado; a busca de semelhanças e diferenças nos modos de educação de gerações ou grupos sociais distintos; a análise da autopercepção socioprofissional e dos modos de vida de professores;

\footnotetext{
${ }^{16}$ Entre esses trabalhos, podemos citar Vianna (1995), no campo da literatura; Mignot, Bastos e Cunha (2000), Lacerda (2003), Melo (2008) e Alcântara (2008) no campo da história da educação. Vianna estudou a escrita memorialística feminina, buscando compreender o processo de composição da escrita memorialística em interação com a construção de uma identidade da mulher no Brasil. Lillian de Lacerda procurou entender as condições de acesso à leitura e os processos de formação de leitoras no Brasil, mediante o estudo da escrita memorialística de doze mulheres nascidas entre 1843 e 1916. Mignot, Bastos e Cunha organizaram uma coletânea de artigos que abordam escritos autobiográficos de tipos diversos e analisam neles aspectos também diversos. Alcântara investigou a docência de Botyra Camorim, uma professora primária, paulista, na primeira metade do século $\mathrm{XX}$, a partir de seus escritos, inclusive sua autobiografia. Melo pesquisou o modo como o médico e escritor mineiro Pedro Nava se apropriou das culturas do escrito no início do século XX, no quadro de um conjunto de práticas de transmissão dessas culturas, usando como fonte principal de sua pesquisa a obra memorialística do autor.
} 
o interesse por um aspecto específico que se constitui em objeto de investigação: a educação doméstica, o trabalho infantil, as primeiras leituras, a visão que se oferece dos professores etc.

Nesse contexto, julgamos merecedor de atenção o aspecto específico do passado da educação matemática (no Brasil), em sentido amplo: interessamnos, então, experiências nas quais estejam envolvidos ensino e/ou aprendizagem de conhecimentos matemáticos, em práticas escolares ou não, e às quais podem estar intrinsecamente relacionados um ou mais dos temas elencados por Antonio Viñao (2000).

\section{História da educação matemática e escrita autobiográfica}

Conceituar e delimitar o campo da história da educação matemática é tarefa complexa, uma vez que, conforme discutimos em outro trabalho (GOMES, 2010), não é possível identificar, na comunidade dos envolvidos com as relações entre história e educação matemática, um consenso a respeito da filiação e identidade desse campo. Acreditamos que não seria mesmo possível tal consenso, levando-se em conta que história, história da matemática, história da educação e educação matemática são termos polissêmicos, associados a campos que, de acordo com os pesquisadores, podem ser vistos sob muitos prismas diferentes.

Não sendo pertinente nem necessário retomar essa discussão, será suficiente adotarmos aqui, como referência principal, a formulação de Miguel e Miorim (2002). Segundo esses autores, o campo de investigação da história da educação matemática se distingue quando "destacamos da atividade matemática aquela dimensão que se preocupa exclusivamente em investigar os processos intencionais de circulação, recepção, apropriação e transformação dessa atividade" e inclui "todo estudo de natureza histórica que investiga, diacrônica ou sincronicamente, a atividade matemática na história, exclusivamente em suas práticas pedagógicas de circulação e apropriação do conhecimento matemático e em práticas sociais de investigação em educação matemática" (MIGUEL; MIORIM, 2002, p. 187). Observa-se, de imediato, que essa conceituação bastante ampla envolve algo mais complexo do que o estudo, ao longo do tempo, das ideias educacionais ou doutrinas pedagógicas relativas à matemática, como talvez se pudesse identificar o campo no caso de uma reflexão menos cuidadosa.

Como mostramos anteriormente, com as citações de Bertrand Russell e Helena Morley, relatos do passado referentes a práticas de circulação e apropriação do conhecimento matemático estão contidos em escritos autobiográficos. Somos remetidos, portanto, não apenas à necessidade de localizar 
esses relatos e à consideração das possibilidades de mapeá-los em diversas formas de escrita autobiográfica com as quais convivemos e às quais temos acesso relativamente fácil nos dias atuais, mas, também, a investigar modos pertinentes de trabalhar esses documentos como fonte ou objeto da história da educação matemática.

É preciso, ainda, ter em vista a existência e disponibilidade de uma enorme quantidade de produções sobre a escrita autobiográfica, encadeadas a estudos dos campos variados da literatura, da história, da antropologia, da psicanálise, para mencionar alguns exemplos. Focalizamos, na seção anterior, um aspecto primordial, a nosso ver, para orientar qualquer esforço na direção desse tipo de investigação - a opção pela história escrita no plural, em consonância com a valorização das individualidades que produzem a escrita autobiográfica. Restanos examinar algumas questões teórico-metodológicas, cuja abordagem precisa ser integrada a projetos de pesquisa que busquem conectar escrita autobiográfica e história.

\section{História e escrita autobiográfica: incursão breve, mas inevitável, pelo território teórico-metodológico}

Se eu fosse historiador, tudo isso se resolveria. Se ficcionista, também. A questão é que o memorialista é a forma anfíbia dos dois e ora tem de palmilhar as securas desérticas da verdade, ora nadar nas possibilidades oceânicas de sua interpretação. E como interpretar? o acontecido, o vivido, o FATO - já que ele, verdadeiro ou falso, visão palpável ou só boato tem importância igual seja um, seja outro. Porque sua relevância é extrínseca e depende do impacto psicológico que provoca. Essa emoção, desprezível para o historiador, é tudo para o memorialista cujo material criador pode, pois, sair do zero. Mentira? Ilusão? Nada disso - verdade. Minha verdade, diferente de todas as verdades. Isso, digamos, se ficarmos só no terreno do presente contado num já futuro (o fugaz presente de agora) que o deforma na medida que também acaba. Porque intervém o tempo, o inexorável tempo. Se o espaço é infinito, não pode ser dividido em distâncias. Só o tempo é função das divisões do espaço - não existe senão convencionalmente. O que chamamos Tempo - passado, presente, mesmo sua dimensão futura - é apenas fabricação da memória (NAVA, 2001, p. 173). 
Ângela de Castro Gomes (2004) adverte-nos que houve e tem havido debates e reflexões sobre a natureza das fontes autobiográficas, sobre os procedimentos de crítica documental a elas e sobre suas potencialidades e limites. Em particular, escreve a autora, tem-se procurado enfrentar a dimensão subjetiva que caracteriza essa documentação, e que é explicitada e acentuada por Pedro Nava no trecho acima, extraído de Chão de ferro, o terceiro volume de suas memórias. Gomes ressalta que trabalhar com a escrita autobiográfica demanda deslocamentos nos procedimentos de crítica às fontes históricas, o que envolve questões relativas ao "erro" ou à "mentira" dos textos em exame. Nesses casos, descarta-se a priori qualquer possibilidade de se saber "o que realmente aconteceu", pois não é essa a perspectiva do registro feito. O que importa para o historiador é exatamente a ótica assumida pelo registro escrito autobiográfico e como seu autor a expressa. Desse modo, o documento auto-referencial não diz "o que houve", mas sim "o que o autor diz que viu, sentiu e experimentou, retrospectivamente, em relação a determinado acontecimento" (GOMES, 2004, p. 15).

Se é precisamente o modo subjetivo que interessa ao pesquisador, trabalhar nessa perspectiva não significa ser menos rigoroso do que assumir a postura radicalmente oposta da pretensão à objetividade e à neutralidade. A impressão de veracidade ao leitor, sendo constitutiva da escrita autobiográfica (lembremos Lejeune e o pacto autobiográfico) implicaria, segundo a autora, a necessidade de o investigador cuidar para não ser enfeitiçado, ou seja, criaria o imperativo de se estar sempre atento ao trabalho de crítica demandado por essa documentação. Gomes destaca que esse trabalho não é maior ou menor do que o necessário com outros tipos de documentos, mas precisa levar em conta as peculiaridades e propriedades da escrita de si. O alerta, no que diz respeito ao caráter de veracidade dos escritos autobiográficos, concerne à questão da percepção da fonte como uma expressão do que verdadeiramente aconteceu. Acreditamos, assim como a autora, que nenhum tipo de documento retrata o que verdadeiramente se passou.

Em um tom um pouco diferente, Peter Gay (1999), em resposta à questão sobre em que medida o farto acervo de autobiografias produzidas no século XIX contribuiria realmente para que o historiador tenha acesso à vida interior de seus autores, afirma que distorções inconscientes ou falsificações deliberadas, em lugar de obstáculos, são indícios das realidades internas desses autores, e, como tal, elementos a serem valorizados. Gay mobiliza o acento na subjetividade, ao mesmo tempo em que aponta os modos de leitura que seriam adequados à abordagem da escrita na primeira pessoa: 
Seguramente não tem importância se uma autobiografia publicada reproduz uma experiência passada ou se inventa, nega ou adorna os fatos. Muitas vezes não há como verificar os relatos autobiográficos; seus narradores são com frequência as únicas testemunhas do que contam. No entanto, mesmo quando a evidência interna ou os depoimentos contemporâneos identificam discrepâncias, essas inconsistências são mais instrutivas do que as confissões impassíveis. As fantasias também são realidades que devem ser interpretadas e o mesmo se pode dizer dos silêncios, esses testemunhos mudos mas expressivos, por vezes mais significativos do que as narrativas mais veementes. Basta ler esses testemunhos na sua intimidade, cética, mas não cinicamente (GAY, 1999, p. 121 - 122).

Todavia, a passagem de Pedro Nava, transcrita na abertura desta seção, não sublinha apenas que a verdade do memorialista é diferente de todas as verdades, enfatizando aquilo que para nós é o parâmetro principal a reger qualquer interpretação do escrito autobiográfico. Voltemos ao texto naviano: "Isso, digamos, se ficarmos só no terreno do presente contado num já futuro (o fugaz presente de agora) que o deforma na medida que também acaba. Porque intervém o tempo, o inexorável tempo" (NAVA, 2001, p. 173). O escritor evoca o tempo como fabricação da memória - o momento da lembrança é diferente do momento do acontecimento, e, concomitantemente, é fugaz e já se desenha como futuro.

Enunciada distintamente, a convivência de tempos diversos no sujeito que lembra, evidenciada nas palavras de Nava, a qual confere ao autobiógrafo o que Peter Gay (1999, p. 156) denomina “dupla visão" na rememoração - o eu que recorda o passado o faz no presente, em outro tempo - surge em duas passagens de conferências de Jorge Luis Borges. Borges recorre a uma de suas reflexões preferidas - a de Heráclito (540-480 a. C.) - para fazer sobressair o mesmo e o outro que habitam o ser humano a cada momento, em virtude do fluir incessante do tempo:

Heráclito disse - e já repeti isso em demasia - que ninguém desce duas vezes o mesmo rio. Ninguém desce duas vezes o mesmo rio porque suas águas mudam. Mas o mais terrível é que nós não somos menos fluidos do que o rio (BORGES, 1985, p. 11).

O presente tem sempre uma partícula de passado, uma partícula de futuro. Em nossa experiência, o tempo 
corresponde sempre ao rio de Heráclito - continuamos a usar essa antiga parábola. É como se não tivéssemos avançado em tantos séculos. Somos sempre o rio de Heráclito, vendo-se refletido no rio e pensando que ele não é Heráclito porque ele foi outras pessoas entre aquele último momento em que viu o rio e este (BORGES, 1985, p. 48).

Para Beatriz Sarlo (2007), a discordância de tempos é inevitável nos relatos em primeira pessoa, e mais: todo ato de discorrer sobre o passado tem uma dimensão anacrônica impossível de ser completamente eliminada. A subjetividade da narrativa autobiográfica, portanto, composta daquilo de que o autor se lembra ou se esquece, daquilo que ele silencia propositalmente, modifica ou cria, e do próprio estilo de sua escrita constitui-se, também, "daquilo que seus instrumentos culturais lhe permitem captar do passado, que suas ideias atuais lhe indicam que deve ser enfatizado", "daquilo que conhece por experiência e pelos meios de comunicação, e que se confunde, depois de um tempo, com sua experiência" (SARLO, 2007, p. 59, grifo nosso). A convivência de tempos diferentes - passado recordado e presente (fugaz) em que o autobiógrafo produz o seu registro escrito - impregna, indelevelmente, a escrita autobiográfica, e, sendo inerente a ela, precisará ser sempre alvo do cuidado do leitor-pesquisador.

Podemos ainda considerar a questão, por vezes lembrada, das relações do texto com seu autor: entende-se que a escrita de si produzida pelo indivíduo moderno tem múltiplas intenções. Não se supõe nem uma presumida essência do autor anterior ao escrito, nem que esse autor é produzido pelo discurso que elabora, nem que haja uma unidade perfeita entre quem escreve e quem é produzido pela escrita (GOMES, 2004). E, de novo seguindo Ângela de Castro Gomes, vale a pena pensar, também, que o distanciamento entre o sujeito que escreve e o sujeito de sua narrativa - o personagem do texto, seja ele uma autobiografia, um diário ou uma carta (e, aqui, caberia acrescentar qualquer outro tipo de escrito autobiográfico) não se dá apenas no plano temporal. Isso, porque a sociedade moderna, que consagrou o individualismo e autorizou "a vivência e a expressão de sentimentos, como os da amizade e do amor, de forma mais próxima, efusiva, informal" (GOMES, 2004, p. 16), também criou códigos para essas formas de expressão. A escrita de si se transforma em prática cultural estratégica para um equilíbrio, sempre precário, entre a expressão e a contenção de si, que se traduz na distância entre autor e personagem do texto e se manifesta nas fórmulas consagradas de escrever cartas, diários e memórias: 
Cartas, como diários, memórias e outras formas de escrita de si aproximam, sendo discursos que mobilizam a sinceridade como valor de verdade, mas não podem, por isso, ser tratadas como formas naturalizadas e espontâneas (GOMES, 2004, p. 22).

No entanto, as formas da escrita de si, mesmo sendo indissociáveis dos códigos sociais de cada época, dão espaço à manifestação da qualidade individual do estilo, que Starobinski (1970) vincula indissoluvelmente ao texto autobiográfico como marca constitutiva. $\mathrm{O}$ estilo indica a relação do autor com seu passado, enquanto revela uma maneira específica de se relatar ao outro e, assim, requer que o leitor-investigador lhe confira atenção. Como escreve Viñao (2000), compreender melhor os escritos autobiográficos implica, também, captar as diferenças de estilo entre os autobiógrafos, que podem optar por modos simples e concisos, afetados e empolados, literariamente belos, meramente descritivos, retratando, em maior ou menor escala, costumes e valores etc. Antonio Viñao se refere, ainda, à necessidade de se conhecer o contexto, os fatos e as pessoas a quem o autobiógrafo alude, bem como as intenções e propósitos motivadores do escrito. Os textos autobiográficos podem ser escritos de modo intimista, ressentido, vingativo, como justificativa, como catarse, como resultado de desejo ou necessidade pessoal do autor. Nessa linha, também é importante atentar ao público a quem o escrito se dirige, procurar identificar se foi produzido visando à publicação em livro, por iniciativa do autor ou alheia, ou se foi projetado apenas para um conjunto circunscrito de leitores.

Vinão (2004) alerta para o fato de que os textos auto-referenciais narram, de modo seletivo, a vida de uma pessoa como se fosse um contínuo; entretanto, todo documento histórico é um fragmento ou vestígio, e todo texto seleciona e cria uma aparência de continuidade que substitui a continuidade real, mas silencia boa parte dela. O pesquisador deverá levar em conta tudo isso, e considerar as possibilidades e dificuldades do escrito autobiográfico, atentando para sua estrutura e disposição, para os critérios de seleção do autor, para aquilo que foi silenciado.

Outro ponto frequentemente enfatizado pelos autores que se voltam para os escritos autobiográficos diz respeito à promoção de interlocuções com outros documentos para complementar a informação fornecida pelos textos autoreferenciais. Defendemos, contudo, que esses diálogos se realizem "sem que uma fonte seja valorada de modo diferenciado, posto que cada um desses recursos 
abre a possibilidade de conhecer perspectivas alternativas, ainda que não poucas vezes conflitantes" (GARNICA; FERNANDES; SILVA, 2011).

Sem pretender constituir, aqui, um inventário completo de diretrizes teórico-metodológicas relevantes para a pesquisa histórica com os escritos autobiográficos, encerramos esta seção explicitando uma ideia essencial quanto à leitura desse tipo de texto, embora não lhe seja exclusiva. Como acontece com qualquer documento, a interpretação do escrito autobiográfico é subjetiva, parcial e situada. As mesmas passagens poderiam ser compreendidas e/ou interpretadas de forma distinta por leitores diferentes, que realizariam análises também subjetivas, parciais e situadas, fundadas em suas vivências e repertórios socioculturais. Em um mesmo texto, um leitor poderia selecionar como mais significativos trechos diante dos quais outro intérprete sentiria indiferença ou mesmo rejeição. Cada pesquisador tem uma maneira própria de selecionar, de um texto autobiográfico, os trechos mais expressivos para sua investigação, e, portanto, o mesmo escrito autobiográfico, como qualquer outro documento que guarda traços do passado, está sempre aberto a novas inquisições. As respostas que serão produzidas para elas resultarão em histórias possíveis, em versões históricas (GARNICA, 2008).

Retomemos, enfim, à luz das ideias discutidas neste texto, nossa motivação para o estudo dos escritos autobiográficos: as possibilidades de conectálos à pesquisa em história da educação matemática.

\section{Escrita autobiográfica e história da educação matemática: indicações e ponderações}

Neste texto, para exemplificar a presença de relatos referentes ao passado da educação matemática em escritos autobiográficos, utilizamo-nos, anteriormente, de passagens transcritas da autobiografia de Bertrand Russell e do diário de Helena Morley, nas quais o filósofo inglês nos conta sua iniciação aos Elementos, de Euclides, e a escritora mineira nos narra suas dificuldades com os estudos de matemática para se habilitar como professora primária na Escola Normal de Diamantina. Outro exemplo, estudado por nós em um trabalho anterior (GOMES, 2008), encontra-se nos livros de memórias de Pedro Nava, em que o autor faz referências detalhadas a professores que teve, descreve a atitude e as práticas pedagógicas desses docentes, e narra os exames que realizou ao concluir o curso secundário no Colégio Pedro II.

A leitura de outras memórias e autobiografias nos tem indicado que, 
sendo a escolarização uma experiência marcante nas vidas das pessoas na qual os conhecimentos matemáticos têm participado com destaque desde os primeiros estudos, é frequente que os autores aludam às diferentes práticas organizadoras da educação escolar, aos procedimentos dos professores, à forma como conduzem o ensino, ao ambiente da sala de aula. Esses escritos possibilitam que tenhamos acesso à cultura matemática escolar de um modo diferente daquele que nos propiciam a legislação, as prescrições curriculares, os livros didáticos e os diversos documentos dos arquivos escolares.

Escritos autobiográficos e memorialísticos nos informam, particularmente, acerca de representações sobre a matemática e seus professores construídas pelos alunos e reelaboradas no momento em que eles se dedicam a escrever sobre suas lembranças. Entre esses escritos, parecem-nos merecer atenção especial aqueles cuja autoria cabe a estudantes que se tornaram professores. Temos constatado que já foram publicadas várias obras desse tipo, redigidas, sobretudo, por docentes que ensinaram matemática na escola primária brasileira, e que, em geral depois que se aposentaram, procuraram relatar suas impressões sobre os alunos, a organização e o funcionamento dos sistemas escolares, as inovações pedagógicas propostas/impostas pelos órgãos gestores, as relações com colegas e profissionais da administração escolar, entre outros temas, contribuindo indispensavelmente para que possamos compreender os modos como esses docentes conduziram a complexa tarefa educacional que assumiram.

É preciso dizer, todavia, que memórias e autobiografias nem sempre enfocam tão detalhadamente a escola e os professores, já que seu tema principal pode muito bem estar situado em experiências de maior destaque na vida dos autores do que suas vivências escolares. Há, ainda, algumas vezes, textos memorialísticos e autobiográficos produzidos por alunos e professores que silenciam sobre o tema específico da educação matemática, mesmo quando não deixam de se referir a muitos outros aspectos da educação escolar. A inexistência de referência à educação matemática, porém, não é algo que acarrete impossibilidade de análises. De fato, até nesses casos, cremos na relevância da leitura dessas obras, tendo em vista que, mesmo sem menções diretas à educação matemática, a abordagem conferida às práticas e à cultura escolar traz aportes importantes às investigações pelo fato de a educação matemática se inserir nessas práticas e nessa cultura, e por ter sido excluída nos registros dessas práticas e cultura. A linguagem do silêncio pode ser eloquente: silêncios têm significados, calar pode ser falar por si só - um autobiógrafo pode não ter feito apontamentos acerca das práticas de circulação, recepção, apropriação e 
transformação de conhecimentos matemáticos em sua vida porque elas não lhe legaram marcas que julgasse suficientemente relevantes para figurarem em sua escrita. O silêncio poderia indicar, ainda, uma intenção de ocultamento desse aspecto que sabemos ter existido.

Para estudos da escrita autobiográfica em conexão com a história da educação matemática, tem-se afigurado a nós que as considerações teóricometodológicas anteriormente postas em relevo constituem um referencial relevante. De fato, nossas leituras têm mostrado que as diferenças entre os sujeitos socioculturais e seus estilos de escrita; os modos como selecionam e analisam suas experiências de vida (e, entre elas, as vinculadas ao nosso interesse principal - as práticas de circulação e apropriação de conhecimentos matemáticos); as intenções com que escreveram e os leitores a quem se dirigem são balizas importantes para a investigação em história da educação matemática conectada à escrita autobiográfica.

Acreditamos, assim, que os conceitos e diretrizes sobre a escrita autobiográfica focalizados neste texto podem ancorar significativamente $\mathrm{o}$ trabalho com as dimensões históricas da educação matemática, tanto no que diz respeito às memórias e autobiografias, formas mais difundidas e acessíveis aos pesquisadores, quanto no que se refere a outras formas de escrita auto-referencial, como as cartas, os diários e os arquivos pessoais.

\section{Referências}

ALCÂNTARA, W. R. R. Uma vida no magistério: fios e meadas da história de uma professora paulista. 2008. 238 f. Dissertação (Mestrado em Educação) - Faculdade de Educação, Universidade de São Paulo, São Paulo, 2008.

ARTIÈRES, P. Arquivar a própria vida. Estudos históricos, Rio de Janeiro: FGVCPDOC, v. 11, n. 21, p. 9-34. 1998.

BORGES, J. L. Cinco visões pessoais. Tradução de M. R. R. da Silva. Brasília: Editora da Universidade de Brasília, 1985.

CAMPOS, J. A. S. Introdução. In: SÊNECA. Cartas a Lucílio. Tradução, prefácio e notas de J. A. Segurado e Campos. Lisboa: Fundação Calouste Gulbenkian, 1991.

CHARTIER, R. Les pratiques de l'écrit. In: ARIÈS, P.;DUBY, G. Histoire de la vie privée.. Paris : Éditions du Seuil, 1986, p. 114 - 161.( Tome III. De la Renaissance aux Lumières) 
Dictionnaire des Auteurs de tous les temps et de tous les pays. Paris: Laffont, 1989.

Dictionnaire des Oeuvres de tous les temps et de tous les pays. Paris: Laffont, 1989.

FOUCAULT, M. A escrita de si. In: FOUCAULT, M. Ética, sexualidade, política. 2. ed. Organização e seleção de textos de M. B. da Mota; Tradução de E. Monteiro e I. A. D. Barbosa. Rio de Janeiro: Forense Universitária, 2010, p. 144 - 162.

GARNICA, A. V. M. A experiência do labirinto: metodologia, história oral e educação matemática. São Paulo: Editora UNESP, 2008.

GARNICA, A. V. M; FERNANDES, D. M.; SILVA, H. Entre a amnésia e a vontade de nada esquecer: notas sobre Regimes de Historicidade e História Oral. Bolema, Rio Claro, v. 25, n. 41, p. 213 - 250, dez. 2011.

GAY. P. O coração desvelado: a experiência burguesa da Rainha Vitória a Freud. Tradução de S. Bath. São Paulo: Companhia das Letras, 1999.

GOMES, A. C. Escrita de si, escrita da História: a título de prólogo. In: GOMES, A. C. (Org.). Escrita de si, escrita da história. Rio de Janeiro: Editora da FGV, 2004, p. 7 - 24.

GOMES, M. L. M. História da educação matemática: a propósito da edição temática do BOLEMA. Bolema. Rio Claro, v. 23, n. 35 A, p. vii - xvii, abril. 2010.

GOMES, M. L. M. Potencialidades da literatura como fonte para a história da educação matemática: a obra de Pedro Nava. Bolema, Rio Claro, v. 21, n.30, p.89 - 110, ago. 2008.

GOULEMOT, J. M. Les pratiques littéraires ou la publicité du privé. In: ARIÈS, P.; DUBY, G. Histoire de la vie privée. Paris : Éditions du Seuil, 1986, p. 372 - 405. ( Tome III. De la Renaissance aux Lumières).

HOUAISS, A.; VILLAR, M. S. Dicionário Houaiss da Língua Portuguesa. Rio de Janeiro: Objetiva, 2001.

LACERDA, L. de. Álbum de leitura: memórias de vida, histórias de leitoras. São Paulo: Editora UNESP, 2003.

LEJEUNE, P. O pacto autobiográfico: de Rousseau à Internet. Organização de J. M. G. Noronha; Tradução de M. I. C. Guedes. Belo Horizonte: Editora UFMG, 2008. 
MELO, J. F. Modos e condições de participação na cultura do escrito: Pedro Nava e a formação na família (1903-1913). 2008. 243 f. Dissertação (Mestrado em Educação) Faculdade de Educação, Universidade Federal de Minas Gerais, Belo Horizonte, 2008.

MIGNOT, A. C.; BASTOS, M. H. C.; CUNHA, M. T. S. Refúgios do eu: história, educação e escrita autobiográfica. Florianópolis: Mulheres, 2000.

MIGUEL, A.; MIORIM, M. A. História da Matemática: uma prática social de investigação em construção. Educação em Revista, Belo Horizonte, n. 36, p. 177 - 203, dez. 2002.

MIRANDA, W. M. Corpos escritos: Graciliano Ramos e Silviano Santiago. São Paulo: Editora da Universidade de São Paulo; Belo Horizonte: Editora UFMG, 1992.

MORLEY, Helena. Minha vida de menina. 5. ed. Rio de Janeiro: José Olympio, 1958.

NAVA, P. S. Chão de Ferro. Cotia: Ateliê Editorial; São Paulo: Giordano, 2001.

NUNES, C. A. A carta sétima. In: NUNES, C. A. Marginalia platonica. Belém: Editora da Universidade Federal do Pará, 1973. p. 219 - 235.

PLATÃO. Diálogos: Fedro, O primeiro Alcibíades; Cartas. Tradução de C. A. Nunes; Coordenação de B. Nunes. Belém: EDUFPA, 2007.

PORFÍRIO. Vida de Plotino. Madrid: Gredos, 1992.

ROUSSEAU, J. J. Les confessions. Paris: Gallimard, 2010. (Préface de J. B. Pontalis. Texte établi par Bernard Gagnebin et Marcel Raymond. Notes de Catherine Koenig. Éditions Gallimard, 1959, pour l'établissement du texte ; 1973, pour la préface et le dossier.)

RUSSELL, B. Autobiografia de Bertrand Russell. Rio de Janeiro: Civilização Brasileira, 1967.

SARLO, B. Tempo passado, cultura da memória e guinada subjetiva. Tradução de R. F. d'Aguiar. São Paulo: Companhia das Letras; Belo Horizonte: Editora UFMG, 2007.

SÊNECA. Cartas a Lucílio. Tradução, prefácio e notas de J. A. S. Campos. Lisboa: Fundação Calouste Gulbenkian, 1991.

STAROBINSKI, J. Le style de l'autobiographie. In: STAROBINSKI, J. La relation critique: l'oeil vivant II. Paris: Gallimard, 1970, p.83 - 99. 
VIANNA, M. J. M. Do sótão à vitrine: memórias de mulheres. Belo Horizonte: Editora da UFMG, 1995.

VIÑAO, A. Las autobiografías, memorias y diarios como fuente histórico-educativa: tipología y usos. Teias: Revista da Faculdade de Educação da UERJ, Rio de Janeiro, v. 1 , n. 1, p. $82-97$, jan./jun. 2000.

VIÑAO, A. Relatos e relações autobiográficas de professores e mestres. In:

MENEZES, M. C. Educação, memória, história: possibilidades, leituras. Campinas:

Mercado de Letras, 2004, p. 333 - 373.

Submetido em Novembro de 2010 . Aprovado em Fevereiro de 2011. 
